\title{
Exploring the business of urology: Financial planning and investment strategies for the urologist
}

\author{
Timothy O. Davies, MD, FRCSC'; Ann Marie Houle, MD, MBA, FRCSC'; J. Stuart Oake, MD, MBA, FRCSC ; \\ Darren Beiko, MD, MBA, FRCSC ${ }^{4}$
}

'Department of Surgery, Division of Urology, McMaster University, Hamilton, ON, Canada; ${ }^{2}$ Department of Surgery, Division of Pediatric Urology, Université de Montréal, Montreal, QC, Canada; ${ }^{3}$ Department of Surgery, Division of Urology, University of Ottawa, Ottawa, ON, Canada; 'Department of Urology, Queen's University, Kingston, ON, Canada

Cite as: Can Urol Assoc J 2019;13(4):102-4. hitp://dx.doi.org/10.5489/cuai.5801

\section{"Investment in knowledge pays the best interest" \\ - Benjamin Franklin}

\section{Introduction}

Personal finance decisions will be quite variable from one urologist to another. A whole host of factors will influence the "right answers" for each physician. In this article, we will focus on general advice and principles for the average urologist. Family financial situation, stage of training/career, and goals will affect each physician differently. Here are some keys to planning for financial success.

\section{Financial planning}

\section{Educate yourself}

Learn about financial planning, insurance, retirement planning, and all aspects of personal finance. As physicians, we receive no formal training in running a small business and managing our own finances. Physicians have little time to devote to this important aspect of everyday life. Educating ourselves on the basics of financial planning is the first step to reducing the risk of a colossal financial error.

There are many introductory books that are available to read to get started. Millionaire Teacher, ${ }^{1}$ Wealthy Barber, ${ }^{2}$ and (physician-specific) White Coat Investor ${ }^{3}$ are excellent places to start. There are a number of websites with valuable information as well (for example, https://www.whitecoatinvestor.com, any of the online financial/retirement calculators, https://canadiancouchpotato.com, etc.). There is a tremendous return if you invest some time on your own finances. Sorting out your own situation early in your career could be the difference in retiring comfortably or not. Boosting your returns on investments or increasing savings through financial education could pay dividends in the millions by the time retirement rolls around.

But in educating ourselves, we need to recognize our limits. As mentioned above, physicians are busy professionals, immersed in our everyday medical practices. Consequently, many of us may not be able to commit adequate time to building a proper ongoing financial planning process, setting goals, creating a plan to reach those goals, and educating ourselves about all of the financial products and tools used to build an investment portfolio. We are, by definition, medical experts, not financial experts. We wouldn't expect a financial advisor to achieve competence, and certainly not excellence, in performing a robotic pyeloplasty because a financial advisor is not a medical expert. So why would we expect any urologist to achieve excellence in financial planning on their own, without a financial advisor? In the end, a financial advisor is there to help us optimize our financial planning.

\section{Set goals}

Talk to your partner/family and discuss goals and priorities, even though this can be difficult. Ask yourselves the important questions: When would you like to retire? How much money do you need to live comfortably in retirement? How would you like to support any family/children? Be sure to reevaluate after major life events and at least every five years. Sitting down with your partner on a regular basis to review your financial situation also reduces a major source of tension in a relationship.

\section{Create a plan to reach your goals}

As Antoine de Saint-Exupery said, "A goal without a plan is just a wish." Be sure to measure twice and cut once. This is true for carpentry, circumcisions, and personal finances. Planning for the future will allow for those goals to be realized. Creating a plan and executing it are the most crucial steps to ensuring financial stability. 
When creating a viable financial plan, one has to be objective. Treat your personal financial situation as you would your practice - like a business.

The first step is to examine your current financial situation. ${ }^{4} \mathrm{~A}$ net worth statement needs to be created. Calculate and record your current assets and liabilities. This is essentially one's own personal balance sheet. Assets should be recorded by their current value. Cash, investments, and investment properties convertible to cash should be included. Your home and other assets that you need to keep using (like your car, clothing, etc.) should not be included in the calculations. If you plan to sell your home to fund retirement, then you would include it in your calculations. Liabilities would include all forms of debt - credit card, car loans, any line of credits. Only include your home mortgage if you counted the home in your assets. Calculating your net worth is the difference between the assets and the liabilities. If possible, calculate over a year or two in several snapshots to give you an idea of how much you are saving or not. Managing one's own balance sheet is one of the most important aspects of achieving strong financial health. ${ }^{4}$ Particularly as interest rates rise or fall, how one manages his/her debt will be directly affected. For example, even though it is psychologically tempting to pay off the debt of a mortgage as soon as possible, when interest rates are very low (i.e., below $3 \%$ ), intentionally not paying off one's mortgage and freeing up more money to invest elsewhere (to achieve a return greater than 3\%) makes perfect sense. When interest rates start to rise, one should manage any current debt, and take on any new debt, with great care and caution.

The next step is to create an income statement. ${ }^{4}$ This document looks at the income (cash in) and the expenses that your family would have over a specific time period. Usually this is examined on a monthly or annual basis. There are many excellent online resources to help with identifying a list of possible expenses. Once you have identified expenses, it is useful to separate those that are discretionary (non-essential). The income statement is the basis for creating a budget moving forward.

\section{Save}

Creating a budget is one way of creating a savings plan. There are several techniques for saving. One does not need to be a miser to save for retirement. Budgeting works for some who like to clearly outline and control where money is spent. Simpler options include the "paying yourself first" strategy. Set aside the money required for fixed and essential expenses, and the amount you need to save for retirement every pay period. In this way, you can spend the rest without worry. Many find this works well without all the details of budgeting.

As urologists, we have spent many years training and do not begin to save for many years beyond our peers. Not only have we lost the ability to save over those lost income years, but we have lost those years of compounding interest. This puts us behind those who start to save for retirement at 23 or 25 years of age. We need to pay back our student debt and make up for the opportunity cost of many years of education and training.

For most of us, we would need to save in excess of $20 \%$ of our income yearly to retire as comfortably as we currently live. This is double what David Chilton would recommend in his bestseller, The Wealthy Barber. ${ }^{2}$ This is a challenge in self-control and careful decision-making. Many urologists have deferred spending in order to train and we watch as our friends have a much better income for more than a decade at the same time as we have been saddled with student debt and loan repayment. This is a TRAP. Do not be ensnared by the thinking that you DESERVE anything. Emotional decision-making will lead to incorrect allocation of discretionary expenses as essential and other poor financial choices. Separating those things we NEED vs. those things we WANT is difficult and challenging for many physicians, but it can be rewarding. Doubling your savings rate will increase your retirement nest egg by a wider margin than doubling your rate of return on investment, and with significantly less risk.

Rather than starting with lofty saving goals, starting small and as early as possible is more important than waiting for years to contribute large sums. The financial power of compounding cannot be overstated, and some may not fully understand how much of an advantage it gives the early saver.

\section{Investment strategies}

\section{How much risk can I tolerate?}

Using financial planning software tools can be invaluable to those who are well-informed, but it can be catastrophic to the less-informed. One pitfall with financial planning tools is that the rate of return can be adjusted to achieve one's goal. In determining goals and plans to achieve those goals, risk must be identified and, in fact, quantified when possible. For example, if we are interested in achieving a high rate of return on an investment and use the high return on investment (ROI) to achieve our goals, we need to be absolutely certain that we understand the risk necessary to achieve the higher rate of return. One danger here is that the expected lofty rates of return may actually cause us to decrease the amount we are saving to achieve our goals. A good financial planner will ensure a thorough risk assessment is performed before any investments are made, and the risk assessment will be revisited (and modified accordingly) periodically after reviewing the performance of investment vehicles. After the risk assessment, your financial advisor should use a rate of return that is aligned with your goals and risk tolerance. 


\section{Things to consider when choosing a financial advisor ${ }^{5}$}

1. Ask family and trusted friends for referrals

2. Experiences with physicians and/or incorporation

3. Qualifications (i.e., certified financial planner)

4. Services provided

a. Investment planning, tax minimization, estate planning, implementation, budgeting

5. How are they paid?

a. Commission

- Generate their income from sales of investment products (i.e., mutual funds)

b. Fee

- Percentage of total assets managed

c. Fee for service

- Flat or hourly fee paid up front for services rendered

- Best way to ensure unbiased advice

\section{How diversified should my portfolio be?}

Diversification can help reduce one's overall financial risk. It is important to diversify within and across major asset classes, such as stocks, bonds, and short-term investments. For example, within one's individual stock holdings, avoiding overconcentration of a single stock and not letting a single stock make up more than $5 \%$ of one's stock portfolio is often advised to maintain an appropriately diversified portfolio. It may be beneficial to further diversify across stocks by market capitalization (small, mid, and large caps), sectors, and region. Even though many financial advisors do not directly invest your money in real estate, a good financial planner will listen to your goals, risk tolerance, and preferences and recommend investing in real estate if it makes sense for you.

\section{Should I hire a financial planner?}

Only with your goals defined, your current financial situation known, and your projected income and expenses outlined can an informed plan be created. The use of an online calculator (https://www.canada.ca/en/services/ benefits/publicpensions/cpp/retirement-income-calculator. $\mathrm{htm} /$ is an unbiased resource) to create a projection is only as good as the assumptions and financials provided. For example, choose realistic estimated rates of return on investment. Manipulating the rates of return, savings rates, and projected expenses will allow you to calculate the boundaries of your financial future.

How accurate or realistic are those calculations? Weigh the complexity of the financial situation. If you are a U.S. citizen, or plan to incorporate your practice, that should factor into your decision. Consider if you have the time, interest, and inclination to correctly consider all the factors involved in creating a good financial plan. Be sure to stay abreast of income tax changes - the most recent changes have altered many physicians' optimal tax planning strategies. For example, the decision to incorporate provides much less flexibility than 12 months ago. Be sure to get individual advice from professionals (accountant and/or financial advisor) when the inevitable future taxation modifications occur. While you may start your own financial planning with the best of intentions, ask yourself if you are likely to sustain your energy, enthusiasm, and dedication to your financial plans and goals, or if it is more likely that you will, like most physicians, neglect your financial plans and goals over time as your practice takes over your life. Many physicians will choose to get outside help because physicians rarely successfully navigate international financial markets to create a dynamic, well-balanced, and appropriately diversified portfolio that achieves their goals. However, understanding the basics of creating a financial plan is key to evaluating a potential advisor and the value of their proposed plan. At the end of the day, we recommend interviewing various financial advisors in order to find the right fit for you and your family. The ultimate goal is to find your "trusted advisor," who will be with you and your family for the long-term and will evolve and change with you during the ups and downs of the financial markets.

\section{Conclusion}

Despite the late start in saving for retirement, there is ample opportunity for urologists to save and plan for comfortable retirement. Educating yourself and developing a plan to get you there are the cornerstones of financial independence.

Competing interests: Dr. Davies has been an advisor for Allergan, Boston Scientific, and Pfizer; and has received grants/honoraria from Allergan, Astellas, Boston Scientific, and Pfizer. Dr. Oake has been an advisor for and has received honoraria from Boston Scientific. Dr. Beiko has received sponsored travel, lodging, and honoraria from Cook Medical. Dr. Houle reports no competing personal or financial interests.

This paper has been peer-reviewed.

\section{References}

1. Hallam A. Millionaire Teacher: The Nine Rules of Wealth You Should Have Learned in School. Wiley. Kindle Edition. 2017.

2. Chilton D. The Wealthy Barber: The Common Sense Guide to Successful Financial Planning. Stoddart. 2002.

3. Dahle JM. The White Coat Investor: A Doctor's Guide To Personal Finance And Investing. The White Coat Investor, LLC. Kindle Edition. 2014.

4. Tyson E. Personal Finance For Canadians For Dummies. Wiley. Kindle Edition. 2016.

5. Carrick R. An insider's guide to choosing a financial advisor. Globe and Mail. Published 2011 Oct 14 [updated 2018 May 8]. Available at: https://www.theglobeandmail.com/globe-investor/investmentideas/an-insiders-guide-to-choosing-a-financial-adviser/article4250772/. Accessed Nov. 29, 2018.

Correspondence: Dr. Timothy 0. Davies, Department of Surgery, Division of Urology, McMaster University, Hamilton, ON, Canada; tdavies@mmaster.ca 